\title{
Luiz Gama por Luiz Gama: carta a Lúcio de Mendonça
}

\section{Ligia Fonseca Ferreira}

Resumo A carta de Luiz Gama a Lúcio de Mendonça, datada de 25 de julho de 1880 , traz a história de vida do único ex-escravo brasileiro que se destacaria como homem de letras e líder dos movimentos abolicionista e republicano. Neste trabalho, pretendemos mostrar como esta carta, em geral considerada de forma isolada, se inscreve numa rede intertextual que modifica e multiplica seus níveis de leitura. Sua originalidade reside tanto no valor do depoimento como nos seus fenômenos enunciativos. Evocamos também a história inédita de um documento que só vem a lume nos anos 1930, cercada de uma polêmica que amplia hoje as possibilidades interpretativas. Por fim, analisar as fronteiras entre os gêneros epistolar e autobiográfico permite-nos questionar em que medida se trata realmente de uma "Autobiografia", tal como esta carta vem sendo apresentada há mais de sessenta anos. Palavras-chave Luiz Gama; escritor negro; Lúcio de Mendonça; cartas; autobiografia; escravidão; abolicionismo; república.

Abstract The letter from Luiz Gama to Lúcio de Mendonça, dated July $25^{\text {th }}, 1880$, brings the story of life of the only Brazilian former slave that was to stand out as scholarly man of letters and leader of the abolitionist and republican movements. In this paper, we propose to show how this letter, generally considered only in isolation, is, in fact, inscribed in an intertextual network that modifies and multiplies reading levels. Originality consists both in the value of the testimony and in its enunciation phenomena. We also evoke the novelty history of a document that only comes to fore in the 1930 s, surrounded by a polemic that widens interpretative possibilities. Finally, to analyze the borders between the epistolary and autobiographical genres allows us to question up to what point this really is an "Autobiography", as this letter has been presented for over sixty years. Keywords Luiz Gama; black writer; Lúcio de Mendonça; letters; autobiography; slavery; abolitionism; republic. 
Nul ne peut écrire la vie d'un homme que lui-même

[Jean-Jacques Rousseau]

No largo do Arouche, em São Paulo, ergue-se, praticamente invisível aos apressados transeuntes, o busto imponente do poeta, jornalista e advogado Luiz Gama (Bahia, 1830 - São Paulo, 1882). Trata-se de um dos raros intelectuais negros brasileiros do século XIX, o único autodidata e também o único a ter sofrido a escravidão, antes de integrar a República das Letras, universo reservado aos brancos. Nascido num Brasil havia pouco independente, era filho, segundo ele, de uma africana e de um pai de origem portuguesa que o venderia, ainda criança, como escravo. Foi nesta condição que chegou à capital paulista, onde viveu por quarenta e dois anos, notabilizando-se como um de seus mais ilustres "cidadãos" Nesta cidade, Gama lançou a primeira edição de seu único livro - Primeiras trovas burlescas de Getulino (1859) -, uma coletânea de poemas satíricos e líricos até bem pouco rara. ${ }^{1}$ Pela primeira vez, na literatura brasileira, um negro ousara denunciar os paradoxos políticos, éticos e morais da sociedade imperial. Após desfrutar do êxito propiciado por uma obra ainda hoje destacada dentro da produção romântica, Luiz Gama se dedicaria a trabalhar em prol de seus sonhos - um "Brasil americano, sem reis e sem escravos"2 - através do jornalismo, da tribuna e dos tribunais. Seu nome se prende igualmente à história da imprensa paulistana como fundador e/ou colaborador de periódicos como Diabo Coxo, Cabrião, O Polichinelo, Correio Paulistano etc. Jamais frequentou escolas, pois, como afirmara, "A inteligência repele os diplomas, como Deus repele a escravidão". Luiz Gama converte-se no incansável e douto "advogado dos escravos" O poeta então se eclipsa, cedendo lugar ao abolicionista e militante republicano.

Ao lado dos versos de "Quem sou eu?", poema-ícone também conhecido como "Bodarrada", a carta de Luiz Gama a Lúcio de Mendonça, com data de 25 de julho

\footnotetext{
1 A segunda edição seria publicada dois anos depois (GAMA, Luiz. Primeiras trovas burlescas. $2^{\mathrm{a}}$ ed., correta e aumentada. Rio de Janeiro: Tipografia de Pinheiro e Cia., 1861). Para a edição mais atual e completa, ver Primeiras trovas burlescas de Luiz Gama e outros poemas, introduçāo e organização Ligia Fonseca Ferreira. São Paulo: Martins Fontes, 2000.

2 GAMA, Luiz. Pela última vez. In: Correio Paulistano, 03 dez. 1869

3 Ibidem.
} 
de $1880,{ }^{4}$ é um de seus textos mais citados e parafraseados desde o surgimento de O precursor do abolicionismo no Brasil em 1938.5 Esta obra, na qual o documento foi reproduzido pela primeira vez, se tornaria a biografia de referência de Luiz Gama por muitos anos. Atualmente, estudiosos e variadas publicações referemno como "Autobiografia", sem dúvida por influência de Fernando Góes, que assim o batizou ao organizar as Obras Completas do autor. ${ }^{6}$

A carta, porém, fundamental para compreensão do ex-escravo que se torna figura destacada no Segundo Império, tem sido alvo de leituras estereotipadas que só levam em consideração, e ao pé da letra, os fatos relatados. Re-examinando-a em seu contexto - ou seja, o tempo (histórico e individual), as motivações que determinaram as condições de produção e recepção -, vêm à tona os elementos objetivos, subjetivos e intersubjetivos que presidiram à sua escritura. Descobre-se, assim, que a carta de Luiz Gama a Lúcio de Mendonça não é um texto autônomo. Logo, uma nova leitura, capaz de integrar esses diferentes aspectos, se impõe.

Em 1991, ao apresentarem a carta de Luiz Gama a Lúcio de Mendonça, rebatizada "Luiz Gama por Luiz Gama", os organizadores do Projeto Rhumor Negro, criado em São Paulo em 1988 por um grupo de escritores negros, são enfáticos: "[Tratase de um] dos mais importantes documentos históricos do povo brasileiro. [...] Face à dimensão da vida deste grande homem, esta carta, atravessando o tempo, é também endereçada a todos nós"'

A menção ao "grande homem" remete a uma ideia que se firma ao longo do século xix. Como observa François Dosse, o "grande homem" é o indivíduo que "conseguiu fazer coincidir sua determinação individual com a vontade coletiva de uma época". ${ }^{8}$ Mas não só, se atentarmos para o fato de que ainda hoje toda uma coletividade - "todos nós", escritores e militantes negros bem como o "povo

4 O manuscrito encontra-se na Biblioteca Nacional (Rio de Janeiro).

5 MENUCCI, Sud. O precursor do abolicionismo no Brasil. São Paulo: Companhia Editora Nacional, 1938, p. 19-26. Mais recentemente, o documento foi incluido na Antologia da carta no Brasil: me escreva tão logo possa. MORAES, Marcos Antonio de (Org.). Sāo Paulo: Moderna, 2005, p. 67-75.

6 In: Obras completas de Luiz Gama. GÓES, Fernando (Org.). São Paulo: Ediçōes Cultura, 1944, p. 177-181. Ver também SCHWARZ, Roberto. Autobiografia de Luiz Gama. Novos Estudos CEBRAP, São Paulo, n²25, outubro de 1989, p. 136-41.

7 Projeto Rhumor Negro (fascículo-programa de atividades), junho de 1991, p. 4-8.

8 DOSSE, François. Le pari biographique. Écrire une vie. Paris: La Découverte, 2005, p. 185 (tradução nossa). 
brasileiro" - se sente destinatária de uma carta que extrapolou sua condição de escrito íntimo.

Qual o conteúdo, as características e o interesse deste documento que, além de continuar ecoando na atualidade, também possui uma história? Como nele se cruzam gênero epistolar e discurso (auto)biográfico?

Na realidade, Luiz Gama escreve para atender a seu jovem amigo Lúcio de Mendonça (1854-1909), que lhe solicitara informações de caráter pessoal, como se depreende das primeiras linhas: "Não me posso negar ao teu pedido [...]: aí tens os apontamentos que me pedes, e que sempre eu os trouxe de memória". 9

Portanto, sem a aludida solicitação, a carta de Luiz Gama contando sua história de vida jamais teria existido e seu teor, que não se explica pela simples curiosidade de um nem pelas confissões espontâneas do outro, reflete uma relação privilegiada entre os interlocutores.

Qual é o estatuto desses homens e que laços os uniam em 1880? Apesar da diferença de idade que os separava por quase uma geração, afinidades políticas e intelectuais nutrem a amizade e projetos comuns. Fervorosos republicanos, participaram juntos da fundação do Partido Republicano Paulista (PRP) do qual Luiz Gama se desligaria praticamente no ato de sua criação, em 1873. Aos 26 anos, o também poeta, jornalista e advogado Lúcio de Mendonça, um dos futuros idealizadores da Academia Brasileira de Letras, gozava de forte prestígio nos meios políticos e intelectuais de São Paulo, Rio e Minas Gerais. Aos 50 anos, Luiz Gama representava uma liderança incontestável nas campanhas abolicionista e republicana de São Paulo, cujos contornos ajudara a definir. Desde o final dos anos 1860, realizava concorridas conferências públicas, escrevia artigos polêmicos nos jornais paulistanos, encabeçava iniciativas para o alforriamento de escravos promovidas pela Loja maçônica América, a maior e a mais popular da cidade, dos quais foi um dos membros fundadores. ${ }^{10} \mathrm{O}$ advogado autodidata havia se transformado em autoridade respeitada em matéria de escravização ilegal e alforriamento de escravos. Terror dos fazendeiros e de advogados e juízes corruptos, sua

9 Carta de Luiz Gama a Lúcio de Mendonça. Op. cit.

10 FERREIRA, Ligia Fonseca. Luiz Gama, franc-maçon. In: Luiz Gama (1830-1882): étude sur la vie et l'oeuvre d'un Noir citoyen, poète et militant de la cause antiesclavagiste au Brésil. Université Paris III, Paris, v. I, 2001, p. 310-39. 
popularidade na província e em outros rincões do Império estava no auge, apesar do grande número de inimigos e adversários políticos. Sua saúde, no entanto, era frágil, mas não o impedia de prosseguir seu trabalho. No momento em que escreve sua carta, Gama encontra-se acometido pelo então mortal diabetes que lhe ceifaria a vida em dois anos, e talvez já suspeitasse que não alcançaria as reformas sociais e políticas às quais dedicara sua vida. Esses motivos decerto justificavam a pressa, por parte de Mendonça, em obter as informações destinadas, como se verá, a um nobre propósito.

Mesmo sendo possível identificar em vários poemas das Primeiras trovas burlescas alusões à sua condição de escravo, certamente o passado daquela figura popular em São Paulo não era conhecido em minúcias. É este o objeto maior das revelações sobre uma vida na qual se entrecruzam o individual e o coletivo. Uma existência, enfim, atravessada por questões candentes do Segundo Império.

Em sua carta, Luiz Gama narra com precisão os episódios dramáticos que têm como ponto de partida seu nascimento e infância numa Bahia agitada por rebeliões negras (1830-1840). Apesar do cunho subjetivo, o estilo do jurista se trai na exposição circunstanciada, e quase distanciada, de suas origens, como se em cinquenta anos sua memória se conservasse intacta. Ao evocar sua filiação, Luiz Gama se apresenta como um típico brasileiro, fruto do "casamento" (ao menos, simbólico) entre África e Portugal, e sugere ter herdado de seus pais, e de sua mãe sobretudo, traços de sua indômita personalidade. Foi graças a esta que conseguiu enfrentar as idiossincrasias sociais e políticas de um país que reservava impiedoso tratamento aos negros, escravos ou não. Escreve Gama:

Nasci na cidade de S[ão] Salvador, capital da província da Bahia, em um sobrado da Rua do Bângala, formando ângulo interno, na quebrada, lado direito de quem parte do adro da Palma, na Freguesia de Sant'Ana, a 21 de junho de 1830, pelas 7 horas da manhã, e fui batizado, 8 anos depois, na igreja matriz do Sacramento, da cidade de Itaparica.

Sou filho natural de uma negra, africana livre, da Costa Mina, (Nagô de Nação) de nome Luíza Mahin, pagã, que sempre recusou o batismo e a doutrina cristã.

Minha mãe era baixa de estatura, magra, bonita, a cor era de um preto retinto e sem lustro, tinha os dentes alvíssimos como a neve, era muito altiva, geniosa, insofrida e vingativa. 
Dava-se ao comércio - era quitandeira, muito laboriosa, e mais de uma vez, na Bahia, foi presa como suspeita de envolver-se em planos de insurreiçōes de escravos, que não tiveram efeito.

Era dotada de atividade. Em 1837, depois da Revolução do Dr. Sabino, na Bahia, veio ela ao Rio de Janeiro, e nunca mais voltou. Procurei-a em 1847, em 1856, em 1861, na Corte, sem que a pudesse encontrar. Em 1862, soube, por uns pretos minas, que conheciam-na e que deram-me sinais certos que ela, acompanhada com malungos desordeiros, em uma "casa de dar fortuna", em 1838 , fora posta em prisão; e que tanto ela como os seus companheiros desapareceram. Em opinião dos meus informantes que esses "amotinados" fossem mandados para fora pelo governo, que, nesse tempo, tratava rigorosamente os africanos livres, tidos como provocadores. [...] Meu pai, não ouso afirmar que fosse branco, porque tais afirmativas, neste país, constituem grave perigo perante a verdade, no que concerne à melindrosa presunção das cores humanas: era fidalgo e pertencia a uma das principais famílias da Bahia de origem portuguesa. Devo poupar à sua infeliz memória uma injúria dolorosa, e o faço ocultando o seu nome.

Ele foi rico; e nesse tempo, muito extremoso para mim: criou-me em seus braços. Foi revolucionário em 1837. Era apaixonado pela diversão da pesca e da caça; muito apreciador de bons cavalos; jogava bem as armas, e muito melhor de baralho, amava as súcias e os divertimentos: esbanjou uma boa herança, obtida de uma tia em 1836; e reduzido à pobreza extrema, a 10 de novembro de 1840 , em companhia de Luiz Cândido Quintela, seu amigo inseparável e hospedeiro, que vivia dos proventos de uma casa de tavolagem, na cidade da Bahia, estabelecida em um sobrado de quina, ao largo da praça, vendeu-me, como seu escravo, a bordo do patacho "Saraiva"."

Como um dos ingredientes de sua história são seus pais, estes ocupam um lugar central no relato. No entanto, tomadas ao pé da letra, as informaçōes contidas nestes parágrafos iniciais alimentaram e continuam alimentando especulações, lendas e ficções em torno do próprio Gama, de seus pais, personagens ambíguos, e especialmente da figura materna. A riqueza de detalhes (dia, hora e local de nascimento; a localização da casa que ainda hoje pode ser vista em Salvador; datas; características físicas e psicológicas e atividades exercidas pelos pais e outros

11 Carta de Luiz Gama a Lúcio de Mendonça. Op. cit. 
personagens; contatos com "testemunhas" etc.) concorre para a criação de "efeitos de real" raramente questionados e, na prática, ainda hoje difíceis de averiguar. Gama construiu uma aura mítica em torno de sua mãe, personagem que ganharia uma espécie de destino próprio, ficcional ou não. Embora o escritor baiano jamais o tenha afirmado em sua carta, muitos atribuíram a ela uma participação histórica, já desmentida, na Revolta dos Malês em $1835,{ }^{12}$ gerando uma crença na sua existência real, fato que lhe reserva um lugar entre os míticos "heróis" afrobrasileiros. Às vésperas do Centenário da Abolição, o fascínio despertado pela africana rebelde e líder revolucionária inspirou poetas negras como Mirian Alves, autora do belo "Mahin amanhã". ${ }^{3}$ Recentemente, uma outra autora mergulharia sem sucesso nos arquivos de Salvador e Itaparica em busca da história de Luiz Gama e de Luiza Mahin, ou quiçá Kehinde, tema do alentado romance Um defeito de cor. ${ }^{14}$ Mas teria Mahin realmente existido? Seria esse seu nome ou possuiria outro como sugere o romance? Luiz Gama teria infringido o contrato em relação à verdade que prometia respeitar? É extremamente perturbador para quem se propõe hoje a (re)fazer sua biografia constatar que, a exemplo de todos os que falam sobre a própria vida, Luiz Gama revela ocultando. Nas pistas mencionadas na carta que nos levariam ao seu registro de batismo, à época equivalente da certidão de nascimento, nada se encontra com seu nome ou com o nome de sua mãe. Ao não revelar o nome do pai, Luiz Gonzaga Pinto da Gama lança dúvidas sobre seu próprio nome e identidade. ${ }^{15}$ Outras ocultações espelhariam as forças que o habitam para safar-se de uma situação aparentemente inextricável: "Em 1848, sabendo eu ler e contar alguma coisa, e tendo obtido ardilosa e secretamente provas inconcussas de minha liberdade, retirei-me, fugindo, da casa do alferes Antônio Pereira Cardoso". ${ }^{16}$

\footnotetext{
12 REIS, João José. O caso Luiza Mahin. In: Rebeliāo escrava no Brasil: a história do Levante dos Malês em 1835 São Paulo: Companhia das Letras, 2003, p. 301-4.

13 In: Cadernos negros n 9. São Paulo: Edição dos autores (Quilombhoje), 1986, p. 46. Este poema faz parte da antologia bilíngue Schwarze Poesie/ Poesia Negra. St. Gallen/Köln: Edition Dia, 1988.

14 GONÇALVES, Ana Maria. Um defeito de cor (romance). Rio de Janeiro: Record, 2006 (951 p.).

15 FERREIRA, Ligia Fonseca. L identité énigmatique de Luiz Gama. In: Luiz Gama (1830-1882): étude sur la vie et l'oeuvre d'un noir citoyen... Op. cit., vol. I, p. 102-10.

16 Carta de Luiz Gama a Lúcio de Mendonça. Op. cit.
} 
A economia narrativa com que Gama evoca esta questão-chave de sua vida é espantosa quando se conhece a complexidade atroz e a lentidão dos processos para o alforriamento de escravos no Brasil. Este nem era o caso do astuto Gama que lograra algo ainda mais difícil: reverter sua frágil condição de escravo e reaver definitivamente sua liberdade. Onze palavras escondiam uma longa história que sem dúvida envolvia o pai, única pessoa a poder comprovar juridicamente que Luiz Gama havia nascido livre. A narrativa instaura, assim, uma ação quase mágica e envolve em certo mistério o passado de Luiz Gama que, de início, promete toda a verdade a seu destinatário.

O relato se estende até o momento em que Luiz Gama travaria conhecimento com o adolescente Lúcio de Mendonça num jornal de propriedade do irmão deste, o também advogado, jornalista e futuro líder republicano Salvador de Mendonça. Ao fazer tal recorte, Gama presume ser desnecessário prosseguir narrando sua vida a alguém já suficientemente informado sobre ela a partir dali:

Agora chego ao período em que, meu caro Lúcio, nos encontramos no Ipiranga, à Rua do Carmo, tu, como tipógrafo, poeta, tradutor e folhetinista principiante; eu como simples aprendiz-compositor, de onde saí para o foro e para a tribuna, onde ganho o pão para mim e para os meus, que são todos os pobres, todos os infelizes; e para os míseros escravos, que, em número superior a 500, tenho arrancado às garras do crime."

Lê-se aí, como em outros momentos da carta, mais uma de suas capitais e sucessivas transformações. De forma compacta, joga-se uma ponte entre o período de mais de uma década que separa o Luiz Gama que se enuncia em 1880, cujo ethos ${ }^{18}$ de abolicionista abnegado e competente aflora em seu próprio discurso, e o Luiz Gama do final dos anos 186o. O período não é escolhido ao acaso. Trata-se de um momento-

17 Carta de Luiz Gama a Lúcio de Mendonça. Op. cit.

18 Noçāo aqui entendida tanto no sentido que Ihe empresta Roland Barthes, ou seja, "os traços de caráter que o orador deve mostrar ao auditório (pouco importa sua sinceridade) para fazer boa impressão, são seus ares [...] o orador enuncia uma informação e ao mesmo tempo ele diz: eu sou isso, eu nāo sou aquilo", quanto no ethos definido por Dominique Maingueneau como imagem de si construída através do discurso e assentada em uma legitimidade social e institucional. Ver AMOSSY, Ruth (dir.). Images de soi dans le discours. La construction de l'ethos. Lausanne: Delachaux \& Niestlé, 1999, respectivamente p. 10 e 17 (tradução nossa). 
chave em que Gama se lança definitivamente na vida pública como porta-voz da luta antiescravista e antimonarquista, coincidindo com uma grande reviravolta na política brasileira. Em 1868, com a queda de Zacarias de Góis, funcionários públicos de diversos escalões e outros indivíduos vinculados ao Partido Liberal, embrião do republicanismo, sofrem perseguições políticas. Luiz Gama, àquela altura amanuense na Secretaria de Polícia de São Paulo, recorda-se da "época em que 'por turbulento e sedicioso' [foi] demitido a 'bem do serviço público', pelos conservadores, que então haviam subido ao poder", 19 retomando em seu discurso as palavras que estigmatizaram, por suas opiniões, o ex-escravo insolente. $\mathrm{O}$ risco era grande, afinal, como escreve o filósofo, é difícil suportar a insolência, principalmente porque é vista não como a denúncia do que é injusto, mas como um ataque a quem pratica a injustiça. ${ }^{20}$ Luiz Gama ousara escancarar os desmandos da lei e desafiar o poder instituído, dos juízes às altas autoridades da província:

A turbulência consistia em fazer eu parte do Partido Liberal; e, pela imprensa e pelas urnas, pugnar pela vitória de minhas e suas ideias; e promover processos em favor de pessoas livres criminosamente escravizadas; e auxiliar licitamente, na medida de meus esforços, alforrias de escravos, porque detesto o cativeiro e todos os senhores, principalmente os reis. ${ }^{21}$

No restrito espaço epistolar, Luiz Gama condensaria suas múltiplas e inauditas metamorfoses: de criança livre a criança escrava, de escravo a homem livre, de analfabeto a homem de letras, de "não-cidadão" a homo politicus; do anonimato à notoriedade, sem esquecer as mudanças de estado associadas às diversas atividades e profissões por ele exercidas (escravo doméstico, soldado, ordenança, copista, secretário, tipógrafo, jornalista, advogado, autoridade maçônica), mudanças provocadas pelas circunstâncias, por adjuvantes ou oponentes, ou simplesmente por obra do tempo. Todas, enfim, testemunhavam a capacidade do personagem de escapar a uma trama de vida previsível, sob o Segundo Império, para um ex-escravo, pobre, órfão, iletrado.

\footnotetext{
19 Carta de Luiz Gama a Lúcio de Mendonça. Op. cit.

20 MEYER, Michel. Del'insolence. Essai sur la morale et le politique. Paris: Grasset, 1995, p. 189

21 Carta de Luiz Gama a Lúcio de Mendonça. Op. cit.
} 
Trama tanto mais improvável por se desenrolar numa cidade inexpressiva como São Paulo que, ao contrário do Rio de Janeiro ou de Salvador, não estava habituada à presença de negros ou de mulatos em ascensão entre os membros de sua elite.

Gama persegue e conquista a palavra escrita, que se converteria em seu ganhapão, apanágio e arma de combate. Na carta, porém, ele não dá nenhum destaque ao fato que coroa seu destino incomum. O ex-escravo analfabeto que recupera a liberdade em 1847 se torna um homem de letras doze anos depois, com a publicação de Primeiras trovas... Ele evoca sua atividade literária em duas palavras ("Fiz versos") e sua íntima relação com a imprensa também aparece de forma lacônica, talvez por modéstia, aparente desapego ou simplesmente por ser do conhecimento de seu destinatário. Em suma, o conteúdo da carta ilustra a transformação alquímica que levou aquele homem a se apossar do conhecimento e da palavra escrita, vedados ao escravo, bem como os subterfúgios que lhe permitiram romper sucessivos laços de dominação até alcançar temerariamente a desejada autonomia. Ao longo de sua narrativa emerge algo que parecia ser sob todos esses aspectos antinômicos: a identidade de "cidadão", do indivíduo com voz influente na pólis, na comunidade de "letrados", vale dizer, na sociedade branca.

Num texto com pouco menos de duas mil palavras, seria impossível fazer a história total de uma personalidade. Luiz Gama se limita a enumerar fatos e ações que falem por si sós. Assim, imagens sucessivas apresentam um indivíduo sensível (a criança e o homem choram), decidido, pronto para o sacrifício e o perdão, seguro, modesto, intransigente, justiceiro, guiado pela razão e animado por uma grande coragem moral. Ataca a instituição "legal" da escravidão armado de argumentos jurídicos e não de fórmulas retóricas, a fim de demonstrar os mecanismos ilegais da justiça que perpetuam o regime servil. Descortina-se uma existência pontuada por transgressões: por um lado, as transgressões cometidas por ele mesmo aos olhos da sociedade (o escravo Luiz aprende a ler e a escrever e foge; quando soldado, enfrenta e ameaça um oficial que o ofendera); por outro lado, transgressões mais graves, cometidas pela justiça e que o advogado e o jornalista Luiz Gama se obstina em denunciar. Mas em meio a tudo, alguns silêncios. Mesmo evocando seu passado entre 1830 e 1850, com algumas "verdades" pouco verificáveis, conforme já se apontou, as informações da carta focalizam particularmente a figura pública. Luiz Gama casou-se em 1869 com uma mulher negra, Claudina 
Fortunata Sampaio, com a qual já tinha um filho, Benedito Graco Pinto da Gama, nascido no mesmo ano do lançamento das Primeiras trovas burlescas.

A riqueza da carta de Luiz Gama a Lúcio de Mendonça repousa, pois, na imbricação de dois níveis distintos de leitura, ou seja, a "realidade da lembrança", de natureza factual, e a "verdade do discurso", razão pela qual será necessário considerar, acima de tudo, que "o termo último de verdade é o ser para si manifestado no presente da enunciação e não o ser em si do passado" 22 Tal é a particularidade das narrativas em primeira pessoa em que o personagem do qual se conta uma história se confunde com a pessoa atual que produz a narração. Em outras palavras, a maneira como Luiz Gama se conta importa tanto quanto, se não mais do que a similitude entre o Luiz Gama figurado através desta narração e a pessoa que ele é no momento em que escreve a Mendonça em 1880. Assim, o narrador é juiz e parte. Surpreendido, no ato da escrita, por este desdobramento a partir do qual assiste, como diria Baudelaire, ao "espetáculo vivo de [sua] triste miséria", Gama deixa de lado o tom de aparente objetividade e parece repentinamente descobrir ali a dimensão arquetípica de sua existência: "Oh! Eu tenho lances doridos em minha vida, que valem mais do que as lendas sentidas da vida amargurada dos mártires". Escrever sobre seu passado sem dúvida exigira de Luiz Gama uma introspecção, uma mudança de perspectiva através da qual ele completava e aprofundava uma identidade que seria dada a ver. Identidade, bem entendido, subjetiva, brotando à medida que se constrói o relato, aproximando-se assim da "identidade narrativa" definida por Paul Ricoeur, segundo o qual esta coloca sempre uma "equação: tal homem igual tal história; e a compreensão que ele tem de si mesmo equivale à capacidade que ele tem de se contar e de se deixar contar" ${ }^{23}$

A um leitor desavisado escaparia a finalidade de uma carta cujo teor fora motivado pelo próprio destinatário, fato que retira a intencionalidade característica do discurso autobiográfico. Certamente, em carta anterior, Lúcio de Mendonça referira sua intenção de usar aquelas informações para redigir a primeira biografia do amigo, biografia de dimensões modestas com o simples título "Luiz Gama”,

\footnotetext{
22 ADAM, Jean-Michel. Le texte narratif. Paris: Nathan, 1994, p. 270 (tradução nossa).

23 RICOEUR, Paul. Identité narrative et communauté historique. Conferência na Journée d'étude de Politique Autrement: "L'idée de la France en question", junho de 1992, p. 11.
} 
publicada no Almanaque Literário de São Paulo para o ano de $1881 .{ }^{24} \mathrm{~A}$ partir dali, aquele nome, quando lembrado, se cercaria sempre de epítetos hiperbólicos, seja no campo historiográfico, na crítica literária, nos meios maçônicos, no discurso de movimentos e intelectuais negros.

- Almanaque Literário..., editado por José Maria Lisboa - conhecido republicano e um dos fundadores d'A Provincia de São Paulo -, era uma publicação de grande circulação na cidade e na província. Pretendia contribuir, conforme anunciava, para a "educação intelectual" e para o divertimento das famílias paulistas das zonas rurais e urbanas, ${ }^{25}$ além de preencher uma lacuna na imprensa local, privilegiando temas paulistas escritos pelos mais diversos autores e personalidades paulistas, dentre eles o próprio Luiz Gama. ${ }^{26}$ A publicação refletia assim os valores culturais e literários da época, e a cada ano trazia artigos biográficos de personalidades paulistas, em sua maioria contemporâneos, que se ilustravam por seus talentos ou realizações pessoais. Tal orientação, longe de ser isolada, ilustrava um gosto e uma prática peculiares ao século XIX, muitas vezes apresentado como o século de ouro da biografia. ${ }^{27} \mathrm{Na}$ Europa, os leitores consomem apaixonadamente as biografias de seus contemporâneos. Na França, e sabemos da influência deste país em nossos espíritos cultos, tenta-se "repertoriar o viveiro de homens que adquiriram certa notoriedade em seu campo de competência, levando a uma proliferação de antologias biográficas que tentam articular individualidade e exemplaridade ${ }^{2{ }^{28} \mathrm{Nas}}$ páginas do Almanaque Literário..., são retratados vários companheiros de Luiz Gama, das fileiras republicanas à loja maçônica América da qual era o venerável. Ali também se encontram publicados inúmeros escritos abolicionistas, nos quais os autores tomavam abertamente partido dos escravos num período em que as revoltas individuais e as fugas das fazendas iam se tornando frequentes.

Imaginemos, então, que por pudor ou modéstia, e padecendo de uma doença incurável, Luiz Gama aceitara que alguém de sua confiança se encarregasse de

\footnotetext{
24 MENDONÇA, Lúcio de. Luiz Gama. In: Almanaque Literário de São Paulo para o ano de 1887. Sāo Paulo: Tipografia da "Província", 1880, p. 50-62. 25 A Província de São Paulo, 04 Out. 1875.

26 Almanaque Literário de São Paulo para o ano de 1879. São Paulo: Tipografia da "Província", 1878, p. IV.

27 DOSSE, François. Op. cit., p. 185 (tradução nossa).

28 Ibidem.
} 
transmitir sua história. Em seu artigo, Mendonça salienta a robustez que, anos antes, emanava do diligente abolicionista, e quase se trai ao manifestar, num tom melancólico, o desejo de que a Abolição e a República o apanhem ainda em vida. ${ }^{29}$ Mas não é apenas ao velho "mestre", à sua futura memória que o artigo pretende servir. A homenagem tem ainda uma segunda finalidade. Atendendo ao projeto pedagógico do Almanaque Literário..., Mendonça procura demonstrar que o exemplo de seu biografado deveria contribuir para restaurar a dignidade de uma família política afetada em sua identidade e corroída por defecções. No início dos anos 1880 , o Partido Republicano acha-se com baixa representatividade nacional, resultado provável da tênue fronteira ideológica entre republicanos e liberais. O retorno destes à presidência do Conselho de Ministros nas eleições parlamentares de 1878 golpeia os republicanos, cuja ascensão tanto os conservadores quanto os liberais desejam conter, aproveitando-se do fato de os republicanos encontrarem-se divididos. De um lado, uma corrente eminentemente urbana, cujos adeptos idealistas abraçam as "utopias desprezadas" pela ordem imperial; de outro, uma corrente rural, descontente com o Imperador, é encarnada por fazendeiros escravistas e outras categorias dependentes da oligarquia cafeeira ${ }^{30} \mathrm{O}$ pomo da discórdia gira em torno da escravidão: manter ou abolir. Porém, alguns republicanos ávidos de ascender rapidamente na carreira política juntam-se ao Partido Liberal. Os líderes republicanos deploram as dissidências que comprometem a existência do partido. Oposto a qualquer ideia de aliança, a seus olhos nefasta para a identidade republicana, Lúcio de Mendonça proclama que um "republicano aliado a liberais ou há de ser mau republicano ou há de ser mau aliado". ${ }^{31}$ Aos embates políticos somavam-se agitaçōes crescentes nas fazendas das zonas cafeeiras. A imprensa paulistana noticia as tensões existentes no seio da massa negra: rebeliōes, fugas e crimes testemunham a resistência dos escravos e disseminam o pânico entre os senhores e outros setores da população. ${ }^{32}$ Entre $1880 \mathrm{e}$

\footnotetext{
29 MENDONÇA, Lúcio de. Op. cit., p. 62.

30 FAORO, Raimundo. Os donos do poder. São Paulo: Globo, 1989, v. 2, p. 453.

31 HOLANDA, Sérgio Buarque de. História geral da civilização brasileira. São Paulo: DIFEL, t. 2, v. 5 (Do império à república), p. 265.

32 MACHADO, Maria Helena Toledo. O plano e o pânico: os movimentos sociais na década da abolição. São Paulo: Edusp, 1994.
} 
1881, quando se publica o artigo de Mendonça sobre Luiz Gama, os agricultores escravagistas mobilizam-se sem trégua para estancar qualquer projeto de emancipação dos escravos e para conter as revoltas nas fazendas. Em 25 de setembro de 1880, a Gazeta da Tarde, propriedade de José do Patrocínio, publicaria uma série de declarações chocantes dos defensores da escravidão no Parlamento.

Vê-se, portanto, que, desde as linhas iniciais de seu artigo, Mendonça coloca como pano de fundo os dilemas então vividos por seus correligionários:

Os republicanos brasileiros, a toda hora abocanhados pela recordação injuriosa de meia dúzia de apostasias, das que negrejam na crônica de todos os partidos, se quisessem com um nome só, que é um alto exemplo de honrada perseverança, tapar a boca aos detratores, podiam lançar-lhes o belo e puro nome que coroa esta página.

Quantos outros iguais oferecem por ventura, desde o começo de sua existência, os nossos velhos partidos monárquicos?

Faz-se em duas palavras o elogio deste homem verdadeiramente grande, grande neste tempo em que só o podem ser os amigos da humanidade: nascido e criado escravo até à primeira juventude, tem depois alcançado a liberdade a mais de quinhentos escravos! ${ }^{133}$

A exemplaridade moral, bem como o vínculo com a terra paulista, se inflam do tom superlativo, das conotações quase bíblicas com que Mendonça retrata o amigo transformado em paradigma, adivinhando, concomitantemente, a continuidade que o destino reservaria à sua empreitada:

A nobre província de S. Paulo, que hoje o estima entre os seus melhores cidadãos, e que ele preza com o entusiasmo que lhe inspiram todas as grandezas democráticas, presumo que há de ser grato ler, em um livro que é particularmente seu, a biografia, já hoje gloriosa, deste bom republicano.

Se chegar a cumprir-se, como eu espero e desejo, o seu elevado destino, possam ser estas linhas obscuras fiel subsídio para cronistas de melhores dias. ${ }^{34}$

33 MENDONÇA, Lúcio de. Luiz Gama. In: Almanaque Literário de São Paulo para o ano de 1881. Ed. cit., p. 50.

34 Ibidem, p. 50-1. 
A glorificação de Gama tinha um caráter pioneiro. Única biografia publicada com ele ainda vivo, o texto prenuncia a avalanche de escritos e homenagens que se multiplicariam em São Paulo e em todo o país nos momentos que se seguem ao seu falecimento. ${ }^{35}$

Evocar a história comum (ou cruzada) da carta de Luiz Gama com o artigo biográfico de Mendonça aparece como indispensável para a compreensão dos dois textos, procedimento ausente de muitos trabalhos onde se fazem referências isoladas a um ou a outro documento. Observe-se, ademais, que, ao longo do tempo, a interpretação de ambos tem variado em função dos diferentes contextos de recepção, até o momento pouco estudados. Em geral, existe uma tendência a considerar, portanto a "ler" a carta de Luiz Gama como um texto autônomo, espontaneamente produzido, sem atentar para sua relação com um texto preexistente e com um texto posterior. Em virtude das características próprias ao gênero, tal tipo de missiva supôs um antes e sugeriu um depois. Como a mensagem epistolar instaura um diálogo produzindo uma "heterogeneidade discursiva", sua leitura deve continuamente levar em conta a existência de uma "fala outra", pois esta fala e a fala do enunciador se combinam para dar um verdadeiro sentido a essa mensagem. Daí a relação intrínseca entre a carta de Luiz Gama com esta "fala outra" de Mendonça. ${ }^{36}$

Até as primeiras décadas do século xx, o artigo biográfico de Mendonça é reproduzido em várias publicações de todo o país, quando então ocorre uma virada na forma de apreensão da vida do autor de Primeiras trovas burlescas. Sua carta, até então desconhecida, viria a público. Nossa pesquisa indicou que isso se dá pela primeira vez possivelmente no início dos anos 1930. Encontramos uma publicação da carta em 13 de maio de 1931, n'O Estado de S. Paulo, ano seguinte ao do centenário do abolicionista. A partir deste momento, dá-se um efeito de palimpsesto: a carta de Luiz Gama vai aos poucos apagando a lembrança do texto biográfico de Mendonça. E do ponto de vista da recepção, ler uma história, um discurso em primeira pessoa gera sentidos diferentes do que ler a mesma história - ou quase - num discurso em terceira pessoa.

35 FERREIRA, Ligia Fonseca. La mort de Luiz Gama et les premiers hommages. In: Luiz Gama (1830-1882): étude sur la vie et l'oeuvre d'un noir citoyen... Op. cit., p. 509-30.

36 AUTHIER-REVUZ, Jacqueline. Hétérogénéité(s) énonciatives(s). In: Langages (Paris), nº 73, 1984, p. 98-111. 
A divulgação da carta acontece de forma problemática. Embora se trate de um dos escritos mais mencionados de Luiz Gama, raramente se aventou que sua existência fora mantida em sigilo por Lúcio de Mendonça e assim permanecera anos depois de sua morte, fato que deveria trazer novos elementos para a abordagem do texto.

O caráter confidencial da missiva esteve no âmago de uma controvérsia gerada pelo aparecimento d'O precursor do abolicionismo no Brasil. O autor, Sud Menucci, observa, antes de reproduzi-la, que a carta é "muito re-editada cá pelo sul, [e] é, ao contrário, pouco conhecida no norte do país" ${ }^{37}$ e se engaja numa espécie de cruzada revisionista em sua obra de "reparação e de reabilitação" 38 a fim de apagar erros anteriores ao seu trabalho. A ocasião era propícia. Lançado em abril de 1938, O precursor do abolicionismo no Brasil precede de algumas semanas o Cinquentenário da Abolição. Em São Paulo, de 1888 a 1938, cada comemoração do 13 de maio, ou ainda dos aniversários de nascimento e morte de Luiz Gama dão ensejo a homenagens oficiais em diferentes círculos. Desde o final do século XIX, o "grande homem" é a única personalidade afro-brasileira a figurar nos manuais de instrução cívica. ${ }^{39} \mathrm{Em}$ crítica amarga e um tanto impertinente, Menucci questionava a legitimidade e o caráter fidedigno do trabalho de Mendonça. Acusa-o de se apossar inescrupulosamente de informações de caráter pessoal, apresentando-se ao público como autor de um "pseudoestudo" que "nada mais era do que uma ampliação de uma carta de Gama, [...] [enfeitada] com alguns adjetivos encomiásticos, [...] poucas observações e fatos referentes à última fase [de sua vida]" ${ }^{40}$ Estas afirmações suscitam uma viva reação por parte de Carlos Süssekind de Mendonça, filho de Lúcio, ${ }^{41}$ graças à qual é possível resgatar uma história até o momento ignorada. $\mathrm{O}$ jornalista comenta que, depois da publicação no Almanaque Literário de São Paulo para o ano de 1881, o artigo biográfico "Luiz Gama” foi publicado uma segunda vez n' O Estado

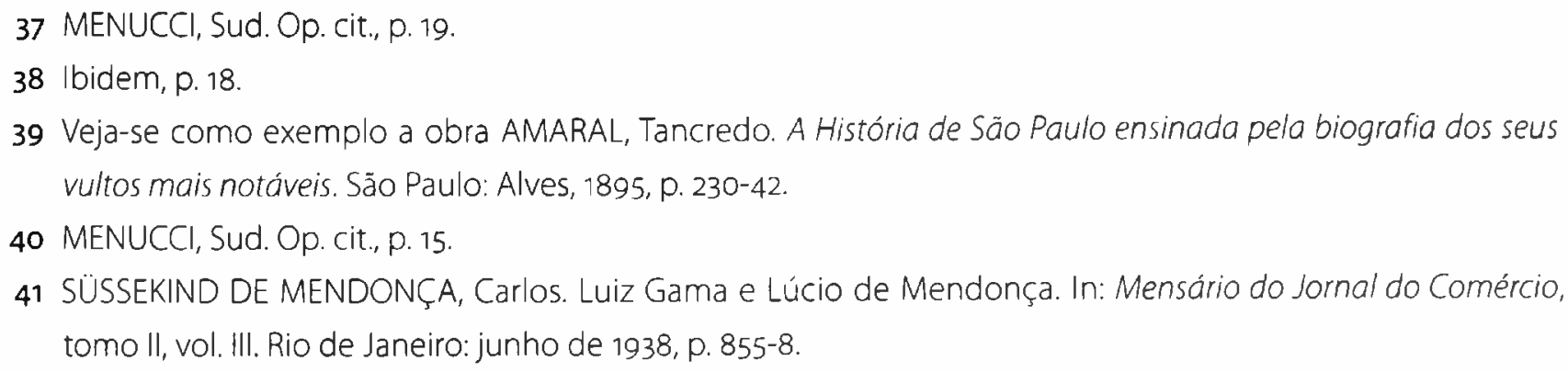


de S. Paulo em 1920, ou seja, onze anos depois da morte de Lúcio de Mendonça. ${ }^{42}$ Logo, até os anos 1920, a carta de Luiz Gama permanecia desconhecida. Süssekind de Mendonça garantia aos leitores que a carta não se encontrava nos arquivos do pai, conservados por ele, razão pela qual ignorava quando e como teria chegado às mãos da imprensa. Sustenta ainda que a confidencialidade da carta deveu-se a um acordo entre os dois amigos, ou antes, a um desejo de Luiz Gama, segundo ele, um homem "modesto e refratário a qualquer ideia de exibicionismo" ${ }^{43}$ As intenções de Lúcio foram, portanto, das mais nobres, conforme demonstrara seu filho, que exigia reparação ao ataque "fantasista", "descortês [...] e injusto" dirigido ao pai. ${ }^{44}$ Süssekind de Mendonça poderia ainda ter lançado mão de outros argumentos. Se as informações fornecidas por Gama tivessem sido utilizadas sem seu aval, ele sem dúvida o teria denunciado com sua costumeira veemência. No mesmo número do Almanaque Literário em que é publicado o artigo de Mendonça, há um poema de Luiz Gama ${ }^{45}$ bem como uma carta escrita por um de seus maiores amigos, José Bonifácio, o Moço (1827-1886). Apresentada como um "documento literário e político precioso", no qual Bonifácio aludia ao desempenho pseudo-heróico do exército brasileiro durante a Guerra do Paraguai, Gama dizia ter conservado a missiva como uma relíquia, antes de entregá-la ao editor do almanaque visando à publicação que constitui, à época, um procedimento de praxe. ${ }^{46}$ Diante de tais evidências, tudo leva a crer que não só Luiz Gama sabia do artigo que lhe prestava homenagem como deve ter concordado com sua forma final.

A polêmica entre Süssekind de Mendonça e Menucci acerca do uso reservado à fonte daquela biografia matricial não parece, pois, desprovida de interesse. Por um lado, elucida a gênese dos documentos. A carta de Luiz Gama desponta como elo

42 Ibidem, p. 858. Posteriormente a 1881, encontramos as seguintes re-edições do artigo de Mendonça: Luiz Gama. O Estado de S. Paulo, 13 maio 1920; Luiz Gama (uma página antiga), O Estado de S. Paulo, 21 jun. 1930 (data do centenário de Luiz Gama); Luiz Gama (uma página escrita há cinquenta anos). In: Revista do Instituto Histórico e Geográfico de Sāo Paulo, n² 28, 1930, p. 433-44; Luiz Gama. In: Revista da Academia Brasileira de Letras, ano 24, vol. 41, março de $1933, n^{\circ} 135$, p. 324-38.

43 SÜSSEKIND DE MENDONÇA, Carlos. Luiz Gama e Lúcio de Mendonça. Ed. cit.

44 Ibidem, p. 856

45 GAMA, Luiz. O moralista. Almanaque Literário de São Paulo para o ano de 1881. Ed. cit., p. 131-5.

46 Uma carta, Idem, p. 201-5 
de uma rede intertextual ligando-a a dois outros textos - o texto que a gerou (carta anterior de Mendonça solicitando os dados), o texto que gerará (biografia redigida por Mendonça), relação que convida a ler com outros olhos os fatos relatados e os fenômenos enunciativos. Por outro, a discussão permite lembrar que a história dos documentos, seu destino material e/ou simbólico, é portadora de sentidos.

Desde que foi revelada ao público, a carta de Luiz Gama adquiriu certa aura e uma dimensão particular do ponto de vista histórico, já que o Brasil teve acesso ao único relato direto da vida de um ex-escravo no país. Este traço garantiria a Luiz Gama um lugar de exceção no panorama intelectual e político brasileiro. No século xIX, entre os raros negros e mulatos que trabalharam em prol do abolicionismo, como é o caso dos jornalistas Ferreira de Menezes (1854-1881) e José do Patrocínio (1853-1905) ou ainda do engenheiro André Rebouças (1838-1898), nenhum passara pela experiência da escravidão. Destes três nomes, apenas José do Patrocínio, filho de uma escrava negra e de um padre branco, fez o relato de um breve período de sua vida (1868-1881) num artigo polêmico publicado em 1884 em seu jornal Gazeta da Tarde. ${ }^{47}$ Talvez se trate do único texto suscetível de comparações com a carta de Luiz Gama. Esta, por outro lado, não apresenta nenhuma afinidade particular com o Diário e notas autobiográficas, de André Rebouças. Abolicionista tardio e ferrenho monarquista, a visão de mundo e as escolhas políticas de Rebouças colocamno em posição diametralmente oposta à do republicano Luiz Gama. Por outro lado, nós nos poderíamos sentir tentados a traçar um paralelo entre a narrativa curta e espontânea do abolicionista brasileiro e as narrativas mais longas e intencionais de dois congêneres norte-americanos. Na história dos negros e das letras brasileiras não há nada equivalente às memórias de escravos tão frequentes no sul dos Estados Unidos, nem a obras autobiográficas comparáveis às de ex-escravos como o futuro jornalista e abolicionista Frederick Douglass (1817-1895), autor de The Life of an American Slave (1845), ou Booker T. Washington (1856-1915), um dos primeiros grandes líderes negros americanos, autor da célebre Up from Slaver $y^{48}$ (1901). A semelhança entre as histórias de vida instigaria uma comparação das trajetórias de Frederick Douglass e Booker T. Washington com a de Luiz Gama.

47 PATROCínIO, José do. Uma explicação. Gazeta da Tarde, São Paulo, 29 maio 1884.

48 A obra foi traduzida no Brasil por Graciliano Ramos, em 1940, com o título Memórias de um negro. 
Porém, a narrativa epistolar do brasileiro não visava aos mesmos objetivos. Tampouco alcançou, enquanto se achava vivo, a mesma repercussão nacional e internacional que as obras de seus pares americanos, obras que, aliás, constituem uma espécie de "fonte mítica" da literatura afro-americana. ${ }^{49}$

Nós nos poderíamos, portanto, perguntar se razões mais íntimas levaram Luiz Gama a contar sua vida ao seu jovem e bem-intencionado amigo. Zonas nebulosas de seu passado prejudicavam sua imagem pública ou criavam dúvidas na mente de seus contemporâneos? Escondia ele alguma coisa capaz de manchar o irrepreensível caminho de quem se entregara de corpo e alma a duas questões cruciais para o Brasil?

Como em todo escrito de natureza autobiográfica, na carta ficam claros os motivos que o levaram a colaborar com o projeto de Mendonça. Quando um indivíduo sente necessidade de contar sua história, é porque talvez haja um conflito entre a imagem que se faz de si próprio e a imagem que os outros lhe devolvem, principalmente se há risco de calúnia..$^{50}$ Assim, Gama se justifica a Mendonça, pensando, como se lê nas entrelinhas, nos que lerão sua história: “[...] quero [antes] ser acoimado de ridículo, em razão de referir verdades pueris que me dizem respeito, do que vaidoso e fátuo, pelas ocultar, de envergonhado. [...]"51

Não se pode dizer que, ao escrever a carta, o enunciador infrinja a regra de discurso segundo a qual não se fala de si, não se enaltece a si próprio, não se chama $a$ atenção do leitor para si. ${ }^{52}$ Embora o faça, não há no discurso de Gama real transgressão, conhecendo-se o uso dos elementos contidos na carta. Deste ponto de vista, é significativa a maneira como avalia sua própria enunciação no último parágrafo do texto, quando parece minimizar, por decoro retórico, a importância de seu relato: "Eis o que te posso dizer, às pressas, sem importância e sem valor; menos para ti, que me estimas deveras".53

\footnotetext{
49 GOODWIN, James. Autobiography: the self-made text. New York, Toronto: Twayne Publishers; Maxwell Macmillan Canada; Maxwell Macmillan International, 1993, p. 46

50 MAY, Georges. L'autobiographie. Paris: P.U.F., 1979, p. 41

51 Carta de Luiz Gama a Lúcio de Mendonça. Op. cit.

52 MAINGUENEAU, Dominique. Pragmatique pour le discours littéraire. Paris: Bordas, 1990, p. 124-5.

53 Carta de Luiz Gama a Lúcio de Mendonça. Op. cit.
} 
No entanto, tal afirmação parece contradizer a necessidade ou a utilidade que o próprio Gama reconhecera em apresentar fatos relativos a sua vida. Notam-se, pois, sob um comportamento aparentemente ambíguo e apesar da modéstia (regra de discurso e regra de polidez), duas certezas identificáveis desde o momento inicial de sua enunciação: a de que seu relato de vida seria lido por outros; e a de que uma história singular, porém desconhecida, como a sua merecia ser publicada.

As confidências presentes na carta confirmam a regra segundo a qual os relatos de natureza autobiográfica tendem sempre a orientar, corrigir ou desmontar representações feitas por outrem em relação ao autor, mesmo se, como lembra Georges May, temos o direito de duvidar da "pureza" de tais confidências, especialmente quando se destinam a finalidades francamente apologéticas. ${ }^{54}$ Contudo, só o próprio Gama podia elucidar suas origens e descartar qualquer versão que veiculasse a falsa imagem de homem "vaidoso". Seus inimigos e adversários estariam espalhando rumores? Visava ele corruptos magistrados e os membros do PRP, do qual se distanciara por considerar inaceitável a presença de fazendeiros escravistas nas hostes republicanas? Talvez seja legítimo imaginar que Mendonça se tenha servido de argumentos desta ordem para convencer o amigo a se abrir sobre seu passado. Os propósitos de ambos parecem ter convergido e a citação acima mostra não só um Luiz Gama aquiescente com a homenagem como convencido da utilidade do projeto. Assim, se em sua carta ele se dirige textualmente a um único destinatário real, discursivamente parece visar destinatários implícitos, nos quais buscaria produzir determinados efeitos, consciente de que sua história seria dada ao público pelas mãos de outro narrador. Seus admiradores se emocionariam com os episódios patéticos pelos quais passara. Quanto aos eventuais detratores, a franqueza de suas revelações faria cair por terra qualquer suspeita ou inverdade relativa ao passado de um homem preocupado em se mostrar sob sua face mais honesta, coerente e verdadeira. Num caso como no outro, a imagem pública e a dignidade política do abolicionista sairiam engrandecidas. Através de sua carta e de todas as circunstâncias que a cercam, pode-se dizer que Gama toma a construção de sua imagem em mãos, pois ao contar sua história de uma certa forma, e deixando-se contar de uma forma subordinada a esta, ele impede que esta mesma história seja contada de outra forma, livre de seu controle. 
Em que medida se poderia considerar a carta de Luiz Gama realmente uma "autobiografia", como vem sendo apresentada há mais de sessenta anos? Fazer este tipo de aproximação sem estabelecer alguns limites acarretaria distorções. A primeira delas, imputando a Gama intuitos narcísicos, de um indivíduo vaidosamente empenhado em dar uma imagem valorizada de si. Mesmo se elementos desta natureza não se encontram totalmente ausentes do texto, tal interpretação só se sustentaria caso a carta tivesse sido efetivamente divulgada logo depois de ser escrita. Seria também esquecer as condições nas quais o documento foi historicamente produzido e lido (carta de uso privado, ausência de projetos de publicação, conhecimento tardio por parte do público).

É provável que traços comuns entre os gêneros autobiográfico e epistolar tenham contribuído para uma espécie de amálgama entre eles. Autobiografia e cartas que "ligam amigos, amantes, parentes e todos os que têm um interesse em comum" fazem parte do que Georges Gusdorf chama de "escritas do eu" 55 Na carta pessoal, contrariamente ao diário íntimo (escrita para si), "o sujeito se enuncia e se anuncia para outrem". ${ }^{6}$ Daí uma certa afinidade enunciativa com a autobiografia, afinidade que não se deveria levar mais longe, pois, sendo o tema igual, não se escreve da mesma maneira, no mesmo dia, uma página de diário íntimo, uma autobiografia ou uma carta.

Talvez seja um pouco abusivo tratar a carta de Luiz Gama como uma autobiografia. Conforme apontou Philippe Lejeune, este gênero se define como "relato retrospectivo em prosa que uma pessoa real faz de sua própria existência, quando ela enfatiza sua vida pessoal, especialmente a história de sua personalidade".57 Além destes elementos formais, a autobiografia supõe igualmente um "contrato de leitura", visto ser, antes de mais nada, um texto destinado a leitores. Quando estes reconhecem a identidade entre o nome do autor-narrador-personagem, dáse o "pacto autobiográfico" ${ }^{58}$ Assim, vemos que, examinado à luz desta noção, o texto de Luiz Gama não atende a esses critérios. Carta privada, ela se dirige a um

\footnotetext{
55 GUSDORF, Georges. Les écritures du moi. Paris: Odile Jacob, 1991, p. 171 (tradução nossa).

56 Ibidem, p. 152.

57 LEJEUNE, Philippe. Le pacte autobiographique. Paris: Seuil, 1975, p. 14 (tradução nossa).

58 Ibidem.
} 
único destinatário e não visa à publicação em seu estado original, fator determinante na medida em que uma autobiografia deve permitir ao leitor associar a um nome próprio o autor/narrador/personagem de uma história de vida contada em primeira pessoa. Ora, a carta a Mendonça não foi naturalmente lida ou recebida nessas condições, pois a autobiografia pressupõe tanto um modo de escritura quanto um modo de leitura proposto de maneira implícita ou explícita ao leitor, contrato que engendra os efeitos característicos do gênero. O scriptor Luiz Gama não selou um pacto autobiográfico em sua carta, mesmo se aos nossos olhos dê tal impressão. Porém, ele soube se construir como um personagem que se transformaria no personagem de uma história produzida por um outro autor-narrador (Mendonça), ao qual caberia por muito tempo a responsabilidade enunciativa de um discurso biográfico.

Personagem de si mesmo, personagem de outrem, o ex-escravo Luiz Gama, consciente de sua singularidade em seu meio e em sua época, cidadão que ao longo da vida dispensou porta-vozes e senhores de seu destino, acabou co-laborando, voluntária ou involuntariamente, para a construção de sua própria lenda que, em nome da História, muitos se encarregariam de manipular. ${ }^{59}$

Ligia Fonseca Ferreira é doutora pela Universidade de Paris 3 - Sorbonne. Organizou a edição das poesias completas deste autor: Primeiras trovas burlescas \& outros poemas [Martins Fontes, 2000].

59 Este artigo baseia-se em parte no capítulo homônimo de minha tese de doutorado Luiz Gama (1830-1882) étude sur la vie et l'oeuvre d'un Noir citoyen, poète et militant de la cause antiesclavagiste au Brésil. Paris: Université Paris III - Sorbonne, 2001 (4 vols.), sob a orientação de Georges Boisvert. 